\title{
Vegetation and water characteristics of floating mat in a coastal lagoon as the habitat for endangered plant species
}

\author{
Mun Gi Hong ${ }^{1}$, Bo Eun Nam ${ }^{1}$ and Jae Geun Kim ${ }^{1,2^{*}}$ (D)
}

\begin{abstract}
Background: To understand the ecological characteristics of floating mat in which endangered species of Iris laevigata and Menyanthes trifoliata inhabit, we surveyed the vegetation and water environments of a floating mat wetland and examined the relations between ecological characteristics of the mat.

Results: Although Phragmites australis and Zizania latifolia were found at all experimental quadrats $(n=61)$ as the major vegetational components of the floating mat wetland, they showed relatively poor growth performances in terms of shoot height $(<2 \mathrm{~m})$ and biomass production $\left(<300 \mathrm{~g} / \mathrm{m}^{2}\right)$ compared with those in soil-based wetlands because of oligotrophic water condition. The competitiveness and distribution of $P$. australis and Z. latifolia seemed to be determined by water level difference by micro-topography rather than water chemistry.

Conclusion: $P$. australis and endangered plant species mainly occurred in the area of relatively shallow water, whereas Z. latifolia and deep-water species such as Scirpus fluviatilis mostly inhabit in the area of deep water on the floating mat. Continuously maintained water level and oligotrophic water condition in the floating mat appeared to be important environments for endangered species such as I. laevigata and M. trifoliata.
\end{abstract}

Keywords: Floating mat wetland, Iris laevigata, Micro-environment, Menyanthes trifoliata, Phragmites australis, Zizania latifolia

\section{Background}

Common reed (Phragmites australis [Cav.] Trin. ex Steud.) and wild rice (Zizania latifolia [Griseb.] Turcz. ex Stapf) are representative emergent macrophytes that play an important role as major vegetational units in wetland ecosystems (Asaeda et al. 2005; Hung et al. 2007). P. australis and Z. latifolia show high competitiveness in wetlands within shore areas of downstream, ponds, and lakes because both species are able to grow at the height of over $3 \mathrm{~m}$ in canopy with dense stands and to rapidly expand particularly under low-velocity flow or lentic conditions (Hong and Kim 2014; Hong et al. 2014; Byun et al. 2017). Rapid growth and expansion of $P$. australis and $Z$. latifolia in wetlands are based on the vigorous below-ground system. They usually invest a

\footnotetext{
* Correspondence: jaegkim@snu.ac.kr

'Department of Biology Education, Seoul National University, Seoul 08826, South Korea

${ }^{2}$ Center for Education Research, Seoul National University, Seoul 08826, South Korea
}

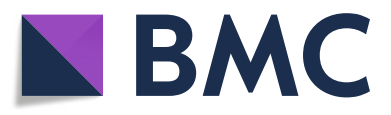

(อ The Author(s). 2018 Open Access This article is distributed under the terms of the Creative Commons Attribution 4.0 International License (http://creativecommons.org/licenses/by/4.0/), which permits unrestricted use, distribution, and

reproduction in any medium, provided you give appropriate credit to the original author(s) and the source, provide a link to the Creative Commons license, and indicate if changes were made. The Creative Commons Public Domain Dedication waiver (http://creativecommons.org/publicdomain/zero/1.0/) applies to the data made available in this article, unless otherwise stated. compared with other macrophytes in terms of biomass allocation under low-nutrient condition (Hung et al. 2007; Hong et al. 2014).

Below-ground parts of well-ventilating tissue, aerenchyma, not only supply oxygen but also make wetland plants likely to float in wetlands. Thus, vigorous below-ground parts possibly enable $P$. australis and $Z$. latifolia to form floating mats making them to have a high tolerance to inundated condition (Cherry and Gough 2006). With vigorousness in growth and expansion, those species often exhibit monotypic occupation in wetlands threatening the biodiversity, whereas they occasionally make floating mats functioning as habitats for other species particularly in deep-water wetlands or lakes (Haraguchi 1991; Tuboi and Hussain 2018). It has also been noted that floating mats could be adequate habitats for weak competitors, including endangered plant species such as Cicuta virosa L. and Menyanthes trifoliata L. (Kim et al. 2013; Shin et al. 2015). 
In this study, we tried to focus on a floating mat mainly composed of $P$. australis and $Z$. latifolia in a coastal lagoon, Sunyoodam, Korea. It has been reported that the floating mat functions as habitats for endangered plant species such as M. trifoliata, Iris laevigata Fisch., and Nymphaea tetragona var. minima (Nakai) W.T. Lee and animal species, such as Kaloula borealis Barbour (Kim et al. 2013). Although the floating mat appeared to play an important role as a biotope for endangered species in Korea, only few studies on the floating mat have been performed so far. In particular, the ecological characteristics of the floating mat focusing on major vegetational components of the mat have not been investigated yet. In this study, we surveyed the vegetation and water environments of the floating mat and examined the relations between the ecological characteristics of the floating mat. We also sought the applicability of floating mats as useful habitats for endangered species.

\section{Materials and methods}

\section{Study site}

The study site located in a freshwater coastal lagoon,

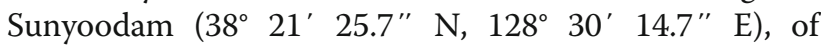
$17,061 \mathrm{~m}^{2}$ in area, which has been isolated from saline water exchange by the construction of embankment in Gangwon Province, Korea. Water sources of the lagoon were the inflow from the surrounding watershed including mountainous areas and paddy fields as the major and rainfall as the minor. It has been reported that the mat consisting of living and dead plant materials had a varying thickness ranging from about 20 to $60 \mathrm{~cm}$, and peat formation in the lagoon has not been reported (Kim et al. 2013).

Most parts of the lagoon except the northern area separated by a dike were filled with a floating mat mainly composed of $P$. australis and $Z$. latifolia (Fig. 1). Open-water areas were maintained along the boundaries between the floating mat and the lagoon for irrigation use. In addition, two endangered plant species of Korea were partly distributed in the lagoon. Most populations of I. laevigata were found on the floating mat, and the others were in the northern area separated from the floating mat by the dike. M. trifoliata populations were mainly found in the southwestern part of the floating mat (Fig. 1).

\section{Field survey}

In order to understand the ecological characteristics of the floating mat focusing on the vegetational components and water environments, a total of 61 quadrats of $1 \mathrm{~m}^{2}$ were placed randomly on the floating mat at intervals of about $6 \sim 7 \mathrm{~m}$ in the growing season (Fig. 1). Assuming that both $P$. australis and $Z$. latifolia would be observed in all of the experimental quadrats as the major vegetational components of the floating mat, the experimental quadrats were classified into two groups in terms of vegetational coverage ( $>50 \%$ in coverage) in the field: $P$. australis-dominated and $Z$. latifolia-dominated quadrats.

Shoot height, density, and coverage of $P$. australis and $Z$. latifolia as the ecological characteristics of the major vegetational components were measured at each quadrat. Instead of the clear cutting of above-ground biomass, the sub-sampling method was used to estimate the above-ground biomass as a less-destructive method. A total of 30 shoots with varying height of each component species $(P$. australis and $Z$. latifolia) were sampled to obtain the allometric equation for estimating the above-ground dry weight (AGDW) of those two species in each quadrat. The equations are as follows:

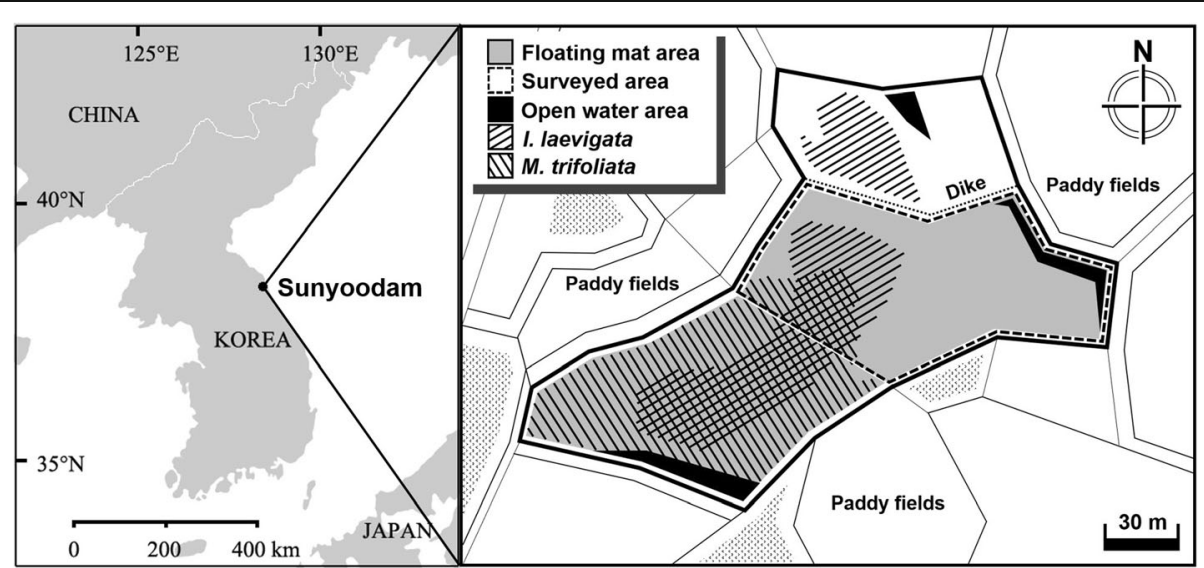

Fig. 1 The study site. Most parts of the lagoon (Sunyoodam) were covered with the floating mat (floating marsh) mostly composed of $P$. australis and Z. latifolia. Meshed areas of endangered plant species do not indicate that those areas were mainly covered with those plant species but mean that those plant species were observed within those areas under the canopies of $P$. australis and $Z$. latifolia 


$$
y=0.1718 x-15.076 \text { for P.australis }\left(R^{2}=0.784, p<.01\right)
$$

$$
y=0.0679 x-3.937 \text { for Z.latifolia }\left(R^{2}=0.732, p<.01\right)
$$

where $y$ is the above-ground dry weight (g), and $x$ is the shoot height $(\mathrm{cm})$.

The regression analysis was performed by using statistical software, SPSS package for Windows (IBM SPSS Version 20.0, New York). As the minor vegetational components, all companion plant species including the endangered species were also recorded.

\section{Analyses on ecological characteristics of the floating mat} Physical (water level from the mat surface and electric conductivity [EC]) and chemical environments of water $\left(\mathrm{pH}, \mathrm{NO}_{3}-\mathrm{N}, \mathrm{NH}_{4}-\mathrm{N}, \mathrm{PO}_{4}-\mathrm{P}, \mathrm{K}^{+}, \mathrm{Ca}^{2+}, \mathrm{Na}^{+}\right.$, and $\mathrm{Mg}^{2+}$ ) were investigated. The physical components of water were measured at the study site. The water level was measured from the mat surface with a wood stick ruler. EC (Corning Checkmate model 311; Corning, USA) and $\mathrm{pH}$ (model AP 63; Fisher, USA) of the water were measured by using portable meters. A total of 61 interstitial water samples ( 1 sample per quadrat) on the floating mat were carried to the laboratory in Seoul National University and filtered by using nitrocellulose membrane filter $(0.45 \mu \mathrm{m})$ for chemical analyses. $\mathrm{NO}_{3}-\mathrm{N}, \mathrm{NH}_{4}-\mathrm{N}$, and $\mathrm{PO}_{4}-\mathrm{P}$ concentrations were analyzed by the hydrazine method (Kamphake et al. 1967), indophenol method (Murphy and Riley 1962), and ascorbic acid reduction method (Solorzano 1969), respectively. Cations $\left(\mathrm{K}^{+}, \mathrm{Ca}^{2+}\right.$, $\mathrm{Na}^{+}$, and $\mathrm{Mg}^{2+}$ ) were measured by using an atomic absorption spectrometer (model AA240FS; Varian, USA). To examine the differences between ecological characteristics and the relations between ecological characteristics of the floating mat, $t$ test and the correlation analysis on all the data of the ecological characteristics were performed by using statistical software, SPSS package for Windows.

\section{Results}

Phragmites australis and Z. latifolia were found at all of the quadrats $(n=61)$ as the major vegetational components. Shoot density, coverage, and AGDW of those two species except shoot height were statistically different at the quadrats of each group ( $P$. australis-dominated, $n=54$; $Z$. latifolia-dominated, $n=7)$. Each dominant species showed approximately twice higher values of shoot density, coverage, and AGDW than the counterpart species. Shoot height of $P$. australis was about $1.5 \mathrm{~m}$, whereas that of $Z$. latifolia was around $1.0 \mathrm{~m}$ throughout the floating mat (Fig. 2).

Most of the environmental characteristics of water chemistry including $\mathrm{NO}_{3}-\mathrm{N}, \mathrm{NH}_{4}-\mathrm{N}, \mathrm{PO}_{4}-\mathrm{P}$, and cations did not show any significant difference between the two dominant groups. In the floating mat, $\mathrm{EC}$ values were around $150 \mu \mathrm{S} / \mathrm{cm}$, and $\mathrm{NO}_{3}-\mathrm{N}, \mathrm{NH}_{4}-\mathrm{N}$, and $\mathrm{PO}_{4}-\mathrm{P}$ concentrations were lower than $1.0 \mathrm{ppm}$. Most concentrations of cations were also lower than $10 \mathrm{ppm}$ except $\mathrm{Na}^{+}$ranging from 7.6 to $21.2 \mathrm{ppm}$ (Fig. 3). On the other hand, those two groups statistically differed in water level and pH (Fig. 3). In particular, water depth in $Z$. latifolia-dominant quadrats $(11.8 \pm 7.2 \mathrm{~cm})$ was more than twice as deep as $P$. australis-dominant quadrats $(4.3 \pm 3.6 \mathrm{~cm})$.

All of the endangered species, I. laevigata (24.1\%) and M. trifoliata $(11.1 \%)$, were recorded in P. australis-dominated quadrats, and they were not observed together in a quadrat. The growth status of major vegetational components and water environments of the quadrats in

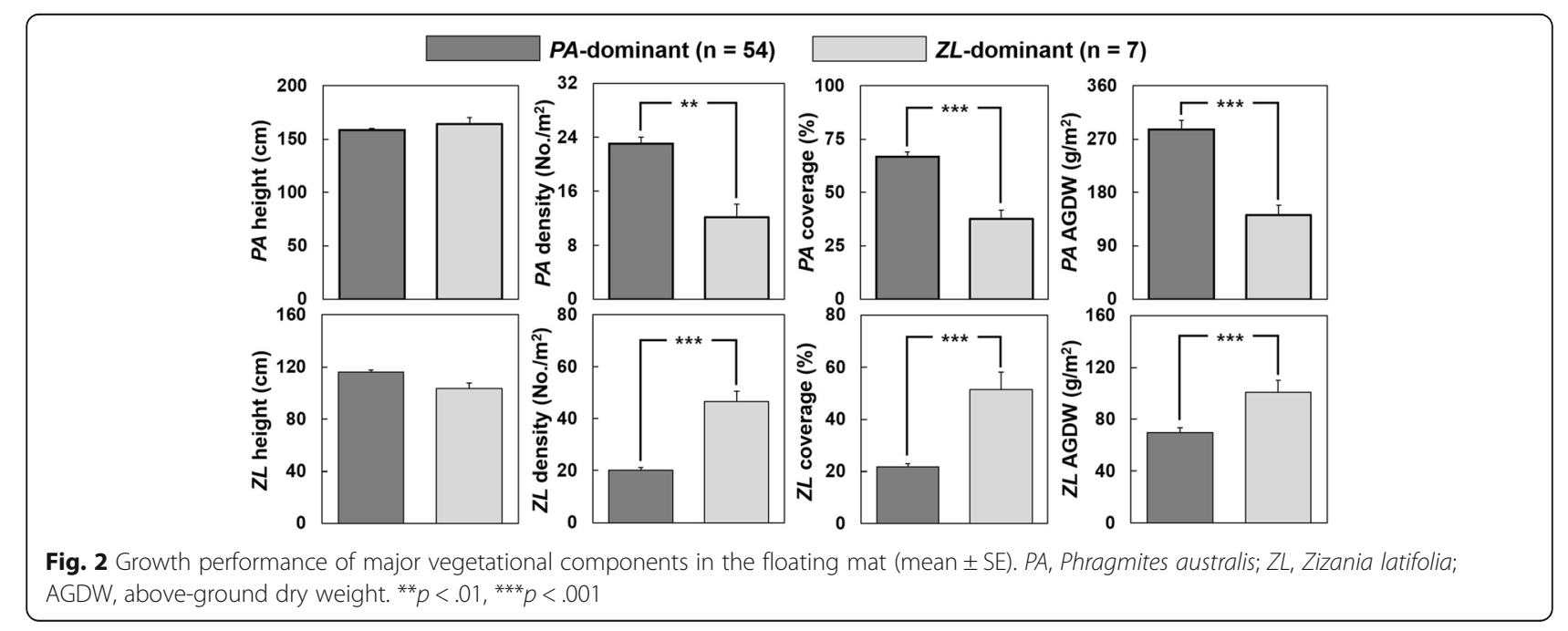




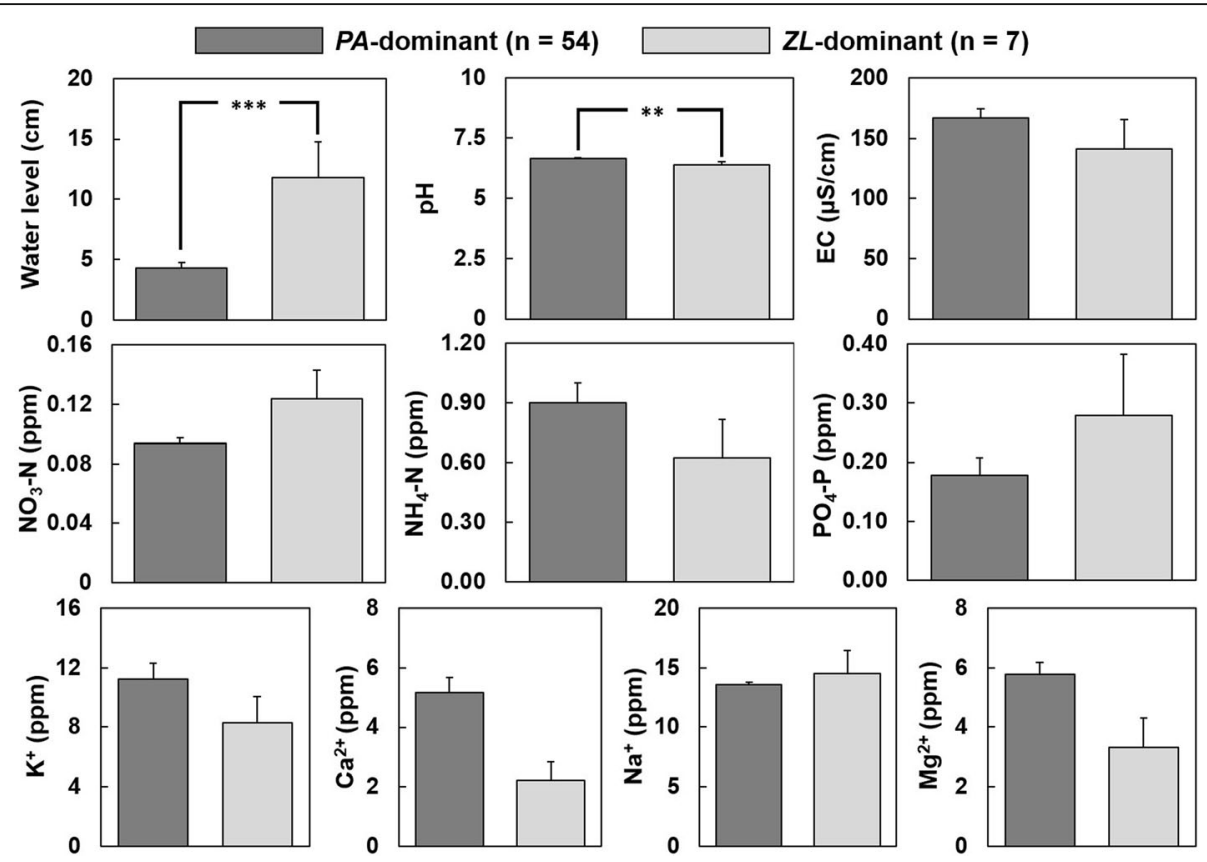

Fig. 3 Physico-chemical characteristics of water environments in the floating mat (mean $\pm S E$ ). PA, Phragmites australis; ZL, Zizania latifolia; EC, electric conductivity. ${ }^{* *} p<.01,{ }^{* * *} p<.001$

which the endangered species was observed did not show a significant difference compared with those in the P. australis-dominated quadrats (Table 1).

In addition to the endangered species, Polygonum thunbergii Seibold \& Zucc. (75.4\%), Carex heterolepis Bunge (57.4\%), Persicaria muricata (Meisn.) Nemoto (24.6\%), and Bidens frondosa L. (13.1\%) were also recorded as minor vegetational components. C. heterolepis was observed only under the canopy of $P$. austrlias, whereas the greater part of Scirpus fluviatilis (Torr.) Gray was found under the canopy of $Z$. latifolia (Table 1). N. tetragona var. minima, one of the endangered plant species that was reported to inhabit in the lagoon (Sunyoodam), was not found via our investigation.

Most values in terms of growth performance such as shoot height, density, coverage, and AGDW of the major vegetational components ( $P$. australis and $Z$. latifolia) were significantly correlated with each other. All values of $P$. australis were positively correlated with each other, whereas shoot height was negatively correlated with density (Pearson's $r=-.408, p<.01$ ) and coverage (Pearson's $r=-.305, p<.05)$ in $Z$. latifoila. On the other side, the density of $Z$. latifolia was negatively correlated with density (Pearson's $r=-.270, p<.05$ ) and biomass (Pearson's $r=-.294, p<.05$ ) of P. australis (Table 2).

The shoot height of $P$. australis (Pearson's $r=.459$, $p<.01$ ) and density (Pearson's $r=.394, p<.01$ ) and coverage (Pearson's $r=.417, p<.01$ ) of $Z$. latifolia were significantly correlated with the water level as a physical characteristic of water environment, whereas most of the values in terms of growth performance did not show significant correlation with chemical environments including $\mathrm{NO}_{3}-\mathrm{N}, \mathrm{NH}_{4}-\mathrm{N}$, and $\mathrm{PO}_{4}-\mathrm{P}$ (Table 2).

\section{Discussion}

Vegetation and water characteristics of the floating mat Micro-topography is of importance in terms of habitat heterogeneity for biodiversity. In wetland ecosystems, water level difference by micro-topography as a physical environment is the most influential factor in determining vegetational components and subsequent biodiversity (Park et al. 2013; Nam et al. 2014; Byun et al. 2017; Kim et al. 2017). In our study, water level difference rather than water chemistry appeared to determine the vegetation of the floating mat (Table 1). Although both $P$. australis and Z. latifolia were found at all quadrats of the floating mat as the major vegetational components, they showed higher competitiveness at different environments in terms of water level. Phragmites australis was the predominant species in most parts of the floating mat of the relatively shallow area, whereas $Z$. latifolia was dominant under deeply inundated area as a deep-water species (Hung et al. 2007). Water level difference between stands of $P$. australis-dominated quadrats and $Z$. latifolia-dominated quadrats has reached up to over $20 \mathrm{~cm}$ in some areas (data not shown). In addition, it seemed likely that the distribution of companion species was also subjected to the difference in water level. Polygonum thunbergii, C. heterolepis, and the 
Table 1 Vegetation and water characteristics of the floating mat

\begin{tabular}{|c|c|c|c|c|c|c|}
\hline \multicolumn{2}{|l|}{ Environmental components } & \multicolumn{3}{|l|}{$P A(n=54)$} & \multirow[t]{2}{*}{$Z L(n=7)$} & \multirow[t]{2}{*}{ Total $(n=61)$} \\
\hline & & $\begin{array}{l}\text { I. laevigata under } P A \\
(n=13)\end{array}$ & $\begin{array}{l}\text { M. trifoliata under PA } \\
(n=6)\end{array}$ & $P A(n=54)$ & & \\
\hline \multirow[t]{8}{*}{ Major components (mean \pm SD) } & PA Shoot height $(\mathrm{cm})$ & $160.9 \pm 10.2$ & $156.6 \pm 12.6$ & $158.5 \pm 11.0$ & $164.2 \pm 15.4$ & $159.2 \pm 11.5$ \\
\hline & Shoot density $\left(\mathrm{no} . / \mathrm{m}^{2}\right)$ & $23.2 \pm 7.7$ & $22.7 \pm 6.3$ & $23.0 \pm 8.0 b$ & $12.2 \pm 4.7 a$ & $21.9 \pm 8.3$ \\
\hline & Coverage (\%) & $66.0 \pm 15.1$ & $69.5 \pm 13.1$ & $66.8 \pm 17.7$ & $37.5 \pm 10.1$ & $63.8 \pm 19.1$ \\
\hline & AGDW $\left(g / m^{2}\right)$ & $288.7 \pm 116.9$ & $263.8 \pm 81.5$ & $286.5 \pm 123.3$ & $141.6 \pm 39.8$ & $271.5 \pm 124.3$ \\
\hline & ZL Shoot height $(\mathrm{cm})$ & $115.2 \pm 15.7$ & 121. \pm 12.1 & $116.2 \pm 13.8$ & $103.4 \pm 11.0$ & $115.2 \pm 14.1$ \\
\hline & Shoot density (no./m²) & $20.9 \pm 9.3$ & $24.8 \pm 9.6$ & $20.1 \pm 8.9$ & $46.5 \pm 9.8$ & $23.0 \pm 12.1$ \\
\hline & Coverage (\%) & $23.9 \pm 12.2$ & $26.8 \pm 12.9$ & $21.6 \pm 10.6$ & $51.5 \pm 6.4$ & $25.0 \pm 14.6$ \\
\hline & AGDW $\left(\mathrm{g} / \mathrm{m}^{2}\right)$ & $68.7 \pm 34.9$ & $101.5 \pm 52.7$ & $69.7 \pm 29.1$ & $100.8 \pm 22.6$ & $74.6 \pm 32.8$ \\
\hline \multirow{9}{*}{$\begin{array}{l}\text { Minor components } \\
\text { (frequency, \%) }\end{array}$} & P. thunbergii & 61.5 & 100 & 79.6 & 33.3 & 75.4 \\
\hline & C. heterolepis & 61.5 & 75.0 & 64.8 & 0 & 57.4 \\
\hline & P. muricata & 15.4 & 0 & 20.0 & 33.3 & 24.6 \\
\hline & B. frondosa & 0 & 16.7 & 12.9 & 16.7 & 13.1 \\
\hline & S. fluviatilis & 0 & 0 & 0.04 & 66.7 & 0.08 \\
\hline & S. tabernaemontani & 0.08 & 0 & 0.04 & 0 & 0.05 \\
\hline & J. effusus & 15.4 & 0 & 0.04 & 0 & 0.03 \\
\hline & 1. globosa & 0.08 & 0 & 0.02 & 0 & 0.03 \\
\hline & H. erectum & 0 & 0 & 0 & 16.7 & 0.02 \\
\hline \multirow[t]{10}{*}{ Water environments (mean $\pm S D$ ) } & Water level (cm) & $6.1 \pm 3.4$ & $5.2 \pm 2.5$ & $4.3 \pm 3.6$ & $11.8 \pm 7.2$ & $5.1 \pm 4.6$ \\
\hline & $\mathrm{pH}$ & $6.6 \pm 0.2$ & $6.7 \pm 0.1$ & $6.7 \pm 0.2$ & $6.4 \pm 0.3$ & $6.6 \pm 0.2$ \\
\hline & $\mathrm{EC}(\mu \mathrm{S} / \mathrm{cm})$ & $160.4 \pm 59.3$ & $218.8 \pm 49.0$ & $167.2 \pm 55.4$ & $141.2 \pm 59.3$ & $165.0 \pm 55.4$ \\
\hline & $\mathrm{NO}_{3}-\mathrm{N}(\mathrm{ppm})$ & $0.10 \pm 0.04$ & $0.09 \pm 0.02$ & $0.09 \pm 0.03$ & $0.12 \pm 0.05$ & $0.10 \pm 0.03$ \\
\hline & $\mathrm{NH}_{4}-\mathrm{N}(\mathrm{ppm})$ & $1.01 \pm 0.91$ & $1.37 \pm 0.88$ & $0.90 \pm 0.77$ & $0.62 \pm 0.48$ & $0.87 \pm 0.74$ \\
\hline & $\mathrm{PO}_{4}-\mathrm{P}(\mathrm{ppm})$ & $0.26 \pm 0.39$ & $0.12 \pm 0.04$ & $0.18 \pm 0.23$ & $0.28 \pm 0.25$ & $0.19 \pm 0.23$ \\
\hline & $\mathrm{K}^{+}(\mathrm{ppm})$ & $9.95 \pm 7.38$ & $15.5 \pm 8.7$ & $11.2 \pm 8.4$ & $8.26 \pm 4.43$ & $10.9 \pm 8.0$ \\
\hline & $\mathrm{Ca}^{2+}(\mathrm{ppm})$ & $4.71 \pm 4.26$ & $5.32 \pm 1.84$ & $5.16 \pm 3.98$ & $2.22 \pm 1.53$ & $4.9 \pm 3.9$ \\
\hline & $\mathrm{Na}^{+}(\mathrm{ppm})$ & $14.2 \pm 1.7$ & $13.2 \pm 0.9$ & $13.6 \pm 1.5$ & $14.5 \pm 4.6$ & $13.7 \pm 2.0$ \\
\hline & $\mathrm{Mg}^{2+}(\mathrm{ppm})$ & $5.25 \pm 3.78$ & $9.72 \pm 1.86$ & $5.77 \pm 3.16$ & $3.31 \pm 2.44$ & $5.6 \pm 3.2$ \\
\hline
\end{tabular}

PA Phragmites australis, ZL Zizania latifolia, AGDW above-ground dry weight, EC electric conductivity

endangered species as shallow-water species were mainly found under the canopy of $P$. australis (Kim et al. 2013; Lee et al. 2018), whereas the greater part of S. fluviatilis as a deep-water species was observed in company with Z. latifolia on the floating mat (Yuan et al. 2007).

In wetland ecosystems, plant species diversity usually decreases with the increase in nutrients because of the monotypic occupation by strong competitors such as $P$. australis and Z. latifolia particularly under eutrophic conditions (Hong et al. 2014; Byun et al. 2017). Thus, wetland ecosystems with the flora of high diversity containing weak competitors such as endangered species tend to be formed under oligotrophic conditions (Hong and Kim 2013; Hong et al. 2017). In our study, the floating mat also appeared to be an oligotrophic habitat. Not only the level of nutrients in water such as $\mathrm{NO}_{3}-\mathrm{N}, \mathrm{NH}_{4}-\mathrm{N}, \mathrm{PO}_{4}-\mathrm{P}$, and cations but also the growth status of the major vegetational components ( $P$. australis and $Z$. latifolia) indicated the oligotrophic condition of the floating mat. In particular, both $P$. australis and Z. latifolia generally grow to over $3 \mathrm{~m}$ in canopy height with dense stands $\left(>2000 \mathrm{~g} / \mathrm{m}^{2}\right)$ in soil-based wetlands on the land (Hong and Kim 2012; Hong et al. 2014). In our study, however, they showed relatively poor growth performances in terms of canopy height $(<2 \mathrm{~m})$ and standing crop production $\left(<300 \mathrm{~g} / \mathrm{m}^{2}\right)$, possibly explaining the co-existence between strong and weak competitors on the floating mat.

\section{Formation process of the floating mat}

Although we could not understand the formation process of the floating mat in detail, it seemed likely that both $P$. australis and $Z$. latifolia could importantly 
Table 2 Pearson's correlation coefficients on vegetation and water characteristics of the floating mat $(n=61)$

\begin{tabular}{|c|c|c|c|c|c|c|c|c|c|c|c|c|c|}
\hline & & \multicolumn{4}{|l|}{$P A$} & \multicolumn{4}{|l|}{$Z L$} & \multirow[t]{2}{*}{ Water level } & \multirow[t]{2}{*}{$\mathrm{NO}_{3}-\mathrm{N}$} & \multirow[t]{2}{*}{$\mathrm{NH}_{4}-\mathrm{N}$} & \multirow[t]{2}{*}{$\mathrm{PO}_{4}-\mathrm{P}$} \\
\hline & & Height & Density & Cover. & AGDW & Height & Density & Cover. & AGDW & & & & \\
\hline \multirow[t]{4}{*}{$P A$} & Height & 1 & $.310^{*}$ & $.409^{* *}$ & $.547^{* *}$ & .234 & .069 & .131 & .124 & $.459^{* *}$ & .088 & -.205 & .112 \\
\hline & Density & & 1 & $.865^{* *}$ & $.949^{* *}$ & .168 & $-.270^{*}$ & -.170 & -.163 & -.125 & .087 & .025 & .050 \\
\hline & Cover. & & & 1 & $.875^{* *}$ & .195 & -.211 & -.123 & -.062 & -.096 & .073 & -.017 & -.042 \\
\hline & AGDW & & & & 1 & $.252^{*}$ & $-.294^{*}$ & -.191 & -.131 & -.097 & .044 & -.023 & .061 \\
\hline \multirow[t]{4}{*}{$Z L$} & Height & & & & & 1 & $-.408^{* *}$ & $-.305^{*}$ & .248 & .050 & -.172 & $.321^{*}$ & .088 \\
\hline & Density & & & & & & 1 & $.893^{* *}$ & $.732^{* *}$ & $.394^{* *}$ & .129 & -.211 & .027 \\
\hline & Cover. & & & & & & & 1 & $.659^{* *}$ & $.417^{* *}$ & .189 & -.111 & .178 \\
\hline & AGDW & & & & & & & & 1 & .215 & -.105 & .011 & -.038 \\
\hline \multicolumn{2}{|c|}{ Water level } & & & & & & & & & 1 & $.372^{* *}$ & -.021 & .250 \\
\hline \multicolumn{2}{|c|}{$\mathrm{NO}_{3}-\mathrm{N}$} & & & & & & & & & & 1 & .192 & $.329^{* *}$ \\
\hline \multicolumn{2}{|c|}{$\mathrm{NH}_{4}-\mathrm{N}$} & & & & & & & & & & & 1 & $.481^{* *}$ \\
\hline \multicolumn{2}{|c|}{$\mathrm{PO}_{4}-\mathrm{P}$} & & & & & & & & & & & & 1 \\
\hline
\end{tabular}

PA Phragmites australis, ZL Zizania latifolia, Cover. coverage, AGDW above-ground dry weight ${ }^{*} p<.05 ;{ }^{* *} p<.01$

contribute to the formation process at different times. As a deep-water species, Z. latifolia might form the mat of a sparse structure as the early stage of mat formation in a deeply inundated environment (Yamasaki 1981). After that, $P$. australis might make the mat more buoyant and stable by adding a large volume of below-ground parts such as rhizomes and roots as the late stage of mat formation (Hung et al. 2007; Hong et al. 2014). In fact, according to the report by Kim et al. (2013) focusing on the M. trifoliata in Sunyoodam lagoon, it seemed likely that P. australis contributed to making the floating mat thicker by vigorously developing below-ground parts.

In this study, the water level difference by microtopography on the floating mat could be the result of temporally different contributions of $Z$. latifolia (the early stage) and $P$. australis (the late stage) in the formation process of the floating mat. Most parts of the floating mat appeared to be in the late stage of mat formation except some boundary areas of relatively deep water in which $Z$. latifolia mainly occurred. Although the floating mat covered most parts of the lagoon as the late stage of mat formation, $Z$. latifolia was observed together with $P$. australis at all quadrats in spite of possible interspecific competition between those species that have been abundantly reported particularly under eutrophic conditions (Yamasaki 1984; Hung et al. 2007). In our study, the reciprocal repression between $P$. australis and $Z$. latifolia seemed to be slight or none. Rather, those two species appeared to complement each other as the major components of the floating mat under oligotrophic condition (Kim et al. 2013).

\section{Floating mat as habitats}

The fact that endangered species were found in the floating mat may not mean that the floating mat has provided optimal environments for those species. Rather, it might indicate that the floating mat has offered relatively better environments for those weak competitors when compared with the growth in the wetlands on the land because of decreased competitive pressure as a result of the oligotrophic condition of the floating mat (Shin et al. 2015; Lee et al. 2018). In addition to the oligotrophic condition, continuously maintained water level on the floating mat regardless of varying water level in the lagoon could also be a favorable environment for endangered species to germinate, grow, and establish stably (Cherry and Gough 2006; Shin et al. 2015).

Artificial floating islands (AFIs), which are artificial floating platforms vegetated with wetland plants, have been abundantly utilized in many countries (Pavlineri et al. 2017). Although AFIs have several ecological functions such as water purification, habitat supply, shoreline erosion protection, and landscape enhancement, most cases of AFIs have been mainly utilized as water purifiers for mitigating eutrophication particularly in Asian countries such as China, Japan, Korea, and Taiwan (Lee et al. 1999; Yao et al. 2011). Based on the floating mat in our investigation as a benchmarking model, we suggest that the role of AFIs as an alternative habitat for weak competitors such as uncommon and endangered species should be addressed particularly under oligotrophic conditions (Shin et al. 2015). We also recommend selecting appropriate component species for AFIs such as P. australis and $Z$. latifolia that invest more energy into the below-ground parts for stability as a floating mat (island) 


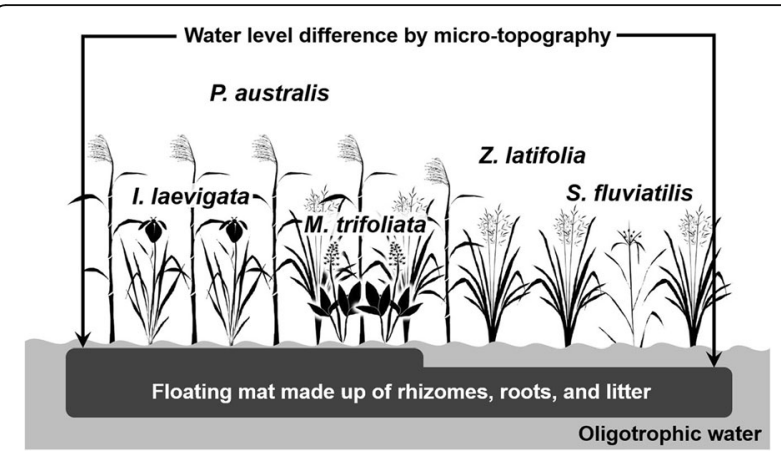

Fig. 4 The schematic diagram indicating a model of artificial floating islands as alternative habitats for endangered plant species under an oligotrophic condition

and making up micro-environments in the water level for biodiversity as a more valuable ecosystem (Fig. 4).

Unlike other types of wetland ecosystem, too little attention has been paid to floating mats in Korea in spite of the high potential in various applications. There have been only few studies on floating mats, and those studies have focused on ecological characteristics of floating mats such as vegetation, water chemistry, and physical structure of mats at a point in time. To understand floating mats in detail for various and wide applications, further studies on changes in biogeochemistry (i.e., nutrient dynamics) and vegetational components (i.e., succession process) of floating mats based on time series analysis are needed.

\section{Abbreviations}

AFIs: Artificial floating islands; AGDW: Above-ground dry weight; EC: Electric conductivity; PA: Phragmites australis; ZL: Zizania latifoila

\section{Acknowledgements}

Not applicable

\section{Funding}

This research was supported by the Basic Science Research Program through the National Research Foundation of Korea (NRF) funded by the Ministry of Education (NRF-2015R1D1A1A01057373) and National Research Foundation of Korea (NRF) grant funded by the Korea Government (MSIT) (NRF2018R1A2B2002267)

\section{Availability of data and materials}

The datasets during and/or analyzed during the current study available from the corresponding author on reasonable request.

\section{Authors' contributions}

MGH designed the study and wrote the manuscript draft. BEN participated in the field works. JGK conceived the study, participated in the design of the study, edited the manuscript draft, and secured the funding. All authors read and approved the final manuscript.

\section{Authors' information}

Not applicable

\section{Ethics approval}

Not applicable

\section{Consent for publication}

Not applicable

\section{Competing interests}

The authors declare that they have no competing interests.

\section{Publisher's Note}

Springer Nature remains neutral with regard to jurisdictional claims in published maps and institutional affiliations.

Received: 16 October 2018 Accepted: 8 November 2018

Published online: 21 November 2018

\section{References}

Asaeda T, Fujino T, Manatunge J. Morphological adaptations of emergent plants to water flow: a case study with Typha angustifolia, Zizania latifolia and Phragmites australis. Freshw Biol. 2005;50:1991-2001.

Byun C, Nam JM, Kim JG. Effects of flooding regime on wetland plant growth and species dominance in a mesocosm experiment. Plant Ecol. 2017;218: $517-27$.

Cherry JA, Gough L. Temporary floating island formation maintains wetland plant species richness: the role of the seed bank. Aquat Bot. 2006;85:29-36.

Haraguchi A. Effect of flooding-drawdown cycle on vegetation in a system of floating peat mat and pond. Ecol Res. 1991;6:247-63.

Hong MG, Kim JG. Growth characteristics of cutting culms sectioned at different positions from three reed population. J Korean Soc Environ Restor Technol. 2012;15:53-62.

Hong MG, Kim JG. Inhabitation characteristics of Sphagnum palustre in abandoned paddy terrace wetland: a case report in Ansan. J Wetl Res. 2013; 15:71-8.

Hong MG, Kim JG. Role and effects of winter buds and rhizome morphology on the survival and growth of common reed (Phragmites australis). Paddy Water Environ. 2014;12(Suppl 1):S203-9.

Hong MG, Nam BE, Kim JG. Effects of soil fertility on early development of wetland vegetation from soil seed bank: focusing on biomass production and plant species diversity. J Plant Biol. 2017;60:241-8.

Hong MG, Son CY, Kim JG. Effects of interspecific competition on the growth and competitiveness of five emergent macrophytes in a constructed lentic wetland. Paddy Water Environ. 2014;12(Suppl 1):S193-202.

Hung LQ, Asaeda T, Fujino T, Mnaya BJ. Inhibition of Zizania latifolia growth by Phragmites australis: an experimental study. Wetl Ecol Manag. 2007;15: 105-11.

Kamphake $L$, Hannah SA, Cohen JM. Automated analysis for nitrate by hydrazine reduction. Water Res. 1967;1:205-16.

Kim HT, Lee GM, Kim JG. The ecological characteristics and conservation counterplan of Menyanthes trifoliata habitat in floating mat in Korean east coastal lagoon, Sunyoodam. J Wetl Res. 2013;15:25-34.

Kim SH, Nam JM, Kim JG. Establishment strategy of a rare wetland species Sparganium erectum in Korea. J Ecol Environ. 2017;41:27.

Lee EH, Lee BE, Kim JG. Effects of water levels and soil nutrients on the growth of Iris laevigata seedlings. J Ecol Environ. 2018:42:5.

Lee K, Jang J, Kim Y, Park B. A study on the floating island for water quality improvement of a reservoir. Korean J Environ Agric. 1999;18:77-82.

Murphy J, Riley JP. A modified single solution method for the determination of phosphate in natural waters. Anal Chem Acta. 1962;27:31-6.

Nam JM, Jeon S, Choi H, Kim JG. Effects of micro-topography on vegetation pattern in Dunchon-dong wetland. J Wetl Res. 2014;16:353-62.

Park J, Hong MG, Kim JG. Relationship between early development of plant community and environmental condition in abandoned paddy terraces at mountainous valleys in Korea. J Ecol Environ. 2013;36:131-40.

Pavlineri N, Skoulikidis N, Tsihrintzis V. Constructed floating wetlands: a review of research, design, operation and management aspects, and data metaanalysis. Chem Eng J. 2017;308:1120-32.

Shin CJ, Nam JM, Kim JG. Floating mat as a habitat of Cicuta virosa, a vulnerable hydrophyte. Landsc Ecol Eng. 2015;11:111-7.

Solorzano L. Determination of ammonia in natural waters by the phenolhypochlorite method. Limnol Oceanogr. 1969;14:799-801.

Tuboi C, Hussain SA. Plant community structure of the floating meadows of a hypereutrophic wetland in the Indo-Burma Biodiversity Hotspot. Aquat Bot. 2018;150:71-81.

Yamasaki S. Growth responses of Zizania latifolia, Phragmites australis and Miscanthus sacchariflorus to varying inundation. Aquat Bot. 1981;10:229-39.

Yamasaki S. Role of plant aeration in zonation of Zizania latifolia and Phragmites australis. Aquat Bot. 1984;18:287-97. 
Yao K, Song S, Zhang Z, Xu J, Zhang R, Liu J, Cheng L, Liu J. Vegetation characteristics and water purification by artificial floating island. Afr J Biotechnol. 2011;10:19119-25.

Yuan L, Liu G, Li W, Li E. Seed bank variation along a water depth gradient in a subtropical lakeshore marsh, Longgan Lake, China. Plant Ecol. 2007; 189:127-37.

Ready to submit your research? Choose BMC and benefit from:

- fast, convenient online submission

- thorough peer review by experienced researchers in your field

- rapid publication on acceptance

- support for research data, including large and complex data types

- gold Open Access which fosters wider collaboration and increased citations

- maximum visibility for your research: over $100 \mathrm{M}$ website views per year

At $B M C$, research is always in progress.

Learn more biomedcentral.com/submissions 